\title{
USO DO GENE XYIA - XILOSE ISOMERASE COMO AGENTE DE SELEÇÃO NA TRANSFORMAÇÃO GENÉTICA DE CITROS
}

\author{
GUSTAVO ALVES PEREIRA
}

Dissertação apresentada à Escola Superior de Agricultura “Luiz de Queiroz”, Universidade de São Paulo, para obtenção do título de Mestre em Agronomia, Área de Concentração: Fitotecnia.

P I R A C I C A B A

Estado de São Paulo - Brasil

Setembro - 2004 


\title{
USO DO GENE XYIA - XILOSE ISOMERASE COMO AGENTE DE SELEÇÃO NA TRANSFORMAÇÃO GENÉTICA DE CITROS
}

\author{
GUSTAVO ALVES PEREIRA \\ Engenheiro Agrônomo
}

Orientadora: Profa. Dra. BEATRIZ MADALENA JANUZZI MENDES

\begin{abstract}
Dissertação apresentada à Escola Superior de Agricultura “Luiz de Queiroz", Universidade de São Paulo, para obtenção do título de Mestre em Agronomia, Área de Concentração: Fitotecnia.
\end{abstract}

P I R A C I C A B A

Estado de São Paulo - Brasil

Setembro - 2004 


\section{Dados Internacionais de Catalogação na Publicação (CIP) DIVISÃO DE BIBLIOTECA E DOCUMENTAÇÃO - ESALQ/USP}

\section{Pereira, Gustavo Alves}

Uso do gene xylA - xilose isomerase como agente de seleção na transformação genética de citros / Gustavo Alves Pereira. - - Piracicaba, 2004.

39 p. : il.

Dissertação (mestrado) - - Escola Superior de Agricultura Luiz de Queiroz, 2004. Bibliografia.

1. Agrobacterium 2. Biotecnologia de plantas 3. Gene 4. Laranja 5. Melhoramento genético vegetal 6 . Plantas transgênicas 7. Plasmídeo 8 . Transformação genética Xilose I. Título

CDD 634.31

\section{"Permitida a cópia total ou parcial deste documento, desde que citada a fonte - O autor"}


Aos meus pais Niceu (in memorian) e Enéas, aos meus irmãos Niceu e Ana Cristina, a minha vó Anna Toledo, aos meus padrinhos Maria Neunice e Norival pela compreensão, carinho, dedicação e pela força nos momentos difíceis.

A minha noivah Elaine Viana pela força e amor dedicado.

DEDICO

Aos meus primos Eduardo, Darlene, Ligia e a minha afilhada Luiza. 


\section{AGRADECIMENTOS}

A DEUS, que sempre me iluminou e me deu força para enfrentar os obstáculos do meu caminho.

À Profa. Dra Beatriz Madalena Januzzi Mendes pela oportunidade, pela orientação, confiança e amizade;

Ao Prof. Dr. Francisco A. A. Mourão Filho pela colaboração durante a realização deste trabalho;

À Escola Superior de Agricultura "Luiz de Queiroz", pela oportunidade de realização do curso de mestrado;

À Capes, pelo suporte através de concessão de bolsa de estudo de mestrado e à Fapesp pelo auxílio financeiro à execução do projeto.

Ào Prof. Dr. Welinton Almeida pelo apoio profissional e pela amizade durante este período;

À Raquel Boscariol, doutoranda do Laboratório de Biotecnologia Vegetal do CENA pelo auxílio, ensinamentos e paciência durante a realização desse trabalho.

Aos colegas de laboratório e de curso Fernanda, Sandra, Carol, Flávio, Márcia, Cantídio, Zizi, Hérika pelo convívio e amizade, e auxílio prestado;

Aos amigos Fernando e Evandro pelo apoio nos momentos difíceis, pelas conversas e risadas;

Aos amigos de república Sivie - Pira, José Júnior ('irmão'), Fernando , Hector, Niceu e Juan pelo apoio em casa, pelo companheirismo, amizade e dedicação; 
Aos amigos Tadeu, Sérgio e Murilo pela amizade sincera e pelo apoio, mesmo à distância;

À Isaura, Élcio, Edgar e Edilson, pelo apoio.

A minha Mãe, pela compreensão nos momentos de ausência, pelo apoio incessante e pelo amor dedicado;

Aos meus primos Eduardo e Darlene pela amizade sincera e pelo apoio em todas as minhas decisões, mesmo à distância;

Ao meu irmão e irmã queridos, Niceu e Ana Cristina pelo apoio, amor e carinho;

Á minha noiva Elaine pela compreensão nos momentos de ausência, pelo apoio incessante e pelo amor dedicado; 


\section{SÚMARIO}

Página

LISTA DE FIGURAS......................................................................... viii

LISTA DE TABELAS ............................................................................ ix

RESUMO

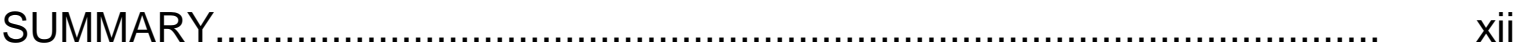

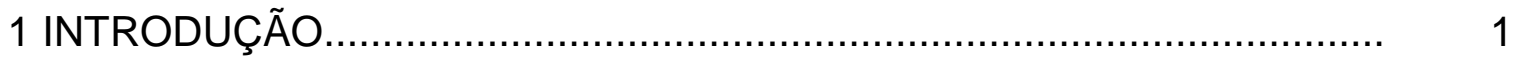

2 REVISÃO DE LITERATURA ............................................................... 4

2.1 Citricultura no Brasil......................................................................

2.2 Transformação Genética de Plantas....................................................... 6

2.3 Transformação Genética em Citros.................................................. 9

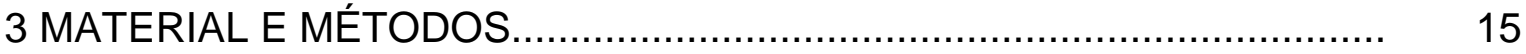

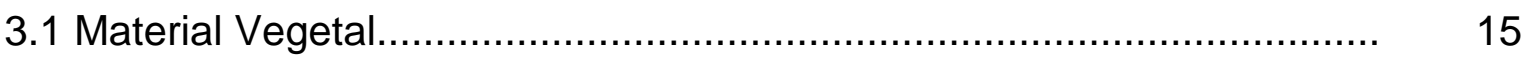

3.2 Avaliação da Sensibilidade dos Explantes a Xilose................................ 15

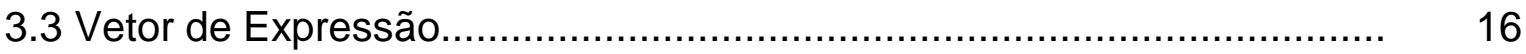

3.4 Cultura de Manutenção dos Isolados de Agrobacterium....................... 17

3.5 Inoculação com Agrobacterium........................................................... 17

3.6 Seleção e Regeneração de Plantas.................................................... 17

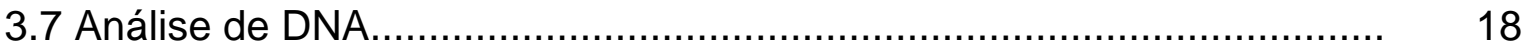

3.8 Microenxertia e Aclimatização.......................................................... 18

3.9 Determinação da Atividade da Enzima Xilose Isomerase....................... 18

4 RESULTADOS E DISCUSSÃO..................................................... 19 


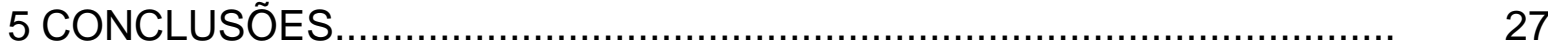

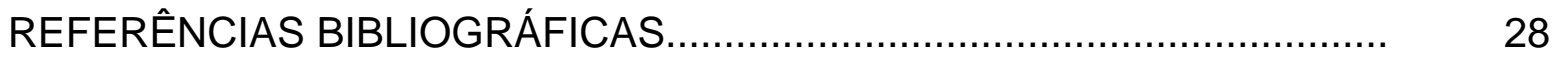




\section{LISTA DE FIGURAS}

Página

1 Plasmídeo utilizado como vetor de expressão...................................... 16

2 Transformação genética a partir de segmentos de epicótilo de laranja 'Natal', 'Pêra', 'Hamlin', 'Valência' com o gene xylA.............................. 26 


\section{LISTA DE TABELAS}

Página

1 Formação de gemas adventícias em segmentos de epicótilo de $C$. sinensis, var. 'Valência' e 'Hamlin', cultivadas em meio de cultura EME suplementado com diferentes fontes de carboidrato $(73 \mathrm{mM})$

2 Formação de gemas adventícias em segmentos de epicótilo de $C$. sinensis, var. 'Valência' e 'Natal', cultivadas em meio de cultura EME suplementado com diferentes combinações de sacarose e xilose.......

3 Regeneração de plantas e eficiência de transformação genética em segmentos de epicótilo de laranja doce, variedades Pêra, Valência, Natal e Hamlin usando o sistema de seleção xylA/xilose (xilose 99 $\mathrm{mM}$, sem acetoseringona no co-cultivo)

4 Regeneração de plantas e eficiência de transformação genética em segmentos de epicótilo de laranja doce, variedades Pêra, Valência, Natal e Hamlin usando o sistema de seleção xylA/xilose (xilose 99 $\mathrm{mM}$, com acetoseringona no co-cultivo) 


\title{
USO DO GENE XYIA - XILOSE ISOMERASE COMO AGENTE DE SELEÇÃO NA TRANSFORMAÇÃO GENÉTICA DE CITROS
}

\author{
Autor: GUSTAVO ALVES PEREIRA \\ Orientadora: Profa. Dra. BEATRIZ MADALENA JANUZZI MENDES
}

\section{RESUMO}

O melhoramento genético das plantas cítricas, pelos métodos tradicionais, é dificultado por uma série de características da biologia de reprodução da espécie. Assim a utilização de técnicas modernas de biotecnologia, como a cultura de tecidos, a manipulação genética e a biologia molecular, têm se mostrado atrativas para o melhoramento genético da cultura. O objetivo deste trabalho é avaliar a transformação genética em variedades de laranja doce (Citrus sinensis) usando o gene $x y \mid A$ como gene de seleção. $O$ trabalho foi realizado com a estirpe EHA 101 de Agrobacterium tumefaciens, contendo o plasmídeo pNOV1457, com o gene xylA. Os isolados da bactéria foram mantidos em meio de cultura YEP suplementado com os antibióticos (ácido nalidíxico, canamicina e estreptomicina). Segmentos de epicótilo foram incubados, por um período de 20 minutos, com a suspensão bacteriana. Após a inoculação, os segmentos foram secos em papel toalha estéril, e incubados em placa de petri $(100 \times 15 \quad \mathrm{~mm})$ contendo 0 meio de cultura 
EME + BAP (1 mg. $\left.\mathrm{L}^{-1}\right)$, em ausência de luz, à temperatura de $24 \mathrm{C}$, por um período de 3 dias, com acetoseringona e sem acetoseringona durante o cocultivo. Após o co-cultivo, os explantes foram transferidos para meio de cultura de seleção e regeneração, constituído do meio de cultura EME + BAP (1 mg. $\left.\mathrm{L}^{-1}\right)$ + cefotaxime $\left(500 \mathrm{mg} \cdot \mathrm{L}^{-1}\right)$ + xilose $\left(15 \mathrm{mg} \cdot \mathrm{L}^{-1}\right)$. A transformação genética foi confirmada pela detecção do gene $x y / A$ nas plantas regeneradas por PCR. A extração do DNA foi feita pelo método de Dellaporta et al. (1983) e as reações de PCR foram conduzidas em termociclador PTC-100 (MJ Research) utilizandose "primers" específicos para detecção do gene xylA. Analisando os dados obtidos verificou-se que foram obtidas plantas transgênicas, utilizando-se 0 sistema xylA/xilose, de 3 variedades de laranja doce Hamlin, Valência e Natal, com uma eficiência de transformação genética variando de 1 - 3\%, em função do experimento e da variedade. A atividade da enzima xilose isomerase foi confirmada pelo teste clorofenol vermelho. Esse trabalho concluiu que é possível a regeneração de plantas transgênicas de variedades de laranja doce utilizando-se o sistema de seleção positiva xylA/xilose. 


\title{
USE OF THE GENE XYIA - XILOSE ISOMERASE A SELECTION AGENT OF IN GENETIC TRANSFORMATION CITRUS
}

\author{
Author: GUSTAVO ALVES PEREIRA \\ Adviser: Profa. Dra. BEATRIZ MADALENA JANUZZI MENDES
}

\section{SUMMARY}

The genetic improvement of the citric plants, by traditional methods, is made difficult by a series species biology reproduction characteristics. The use of modern biotechnology techniques, as tissue culture, the genetic manipulation and molecular biology, have shown attractive for the culture genetic improvement. The objective of this work was to evaluate the genetic transformation in varieties of sweet orange (Citrus sinensis) using the gene $x y / A$ as selection gene. The work was carried out with the EHA 101 Agrobacterium tumefaciens, containing the plasmid pNOV1457, whith the gene $x y / A$. The bacterium was culture in YEP media supplemented with antibiotics (nalidixic acid, kanamicyn e streptomycin). Epicotyl segments were incubated, for $20 \mathrm{~min}$, with the bacterial suspension. After inoculation, the segments were dry in a sterile paper, and incubated in a petri dish $(100 \times 15 \mathrm{~mm})$ containing the medium EME +

BAP ( $\left.1 \mathrm{mg}^{\mathrm{L}}{ }^{-1}\right)$, in dark, at the temperature of $24^{\circ} \mathrm{C}$, for a period of 3 days, with 
and without acetoseryngone during the co-culture period. After the co-culture, the explants were transferred to culture medium of selection and regeneration, consisting of medium EME + BAP $\left(1 \mathrm{mg} \cdot \mathrm{L}^{-1}\right)+$ cefotaxime $\left(500 \mathrm{mg} \cdot \mathrm{L}^{-1}\right)+$ xylose $\left(15 \mathrm{mg} \cdot \mathrm{L}^{-1}\right)$. The genetic transformation was confirmed by the gene detection by PCR. The DNA extraction was done by Dellaporta et al. (1983). PCR reactions were done in a thermal cycler PTC-100 (MJ Research) using specific "primers" for gene $x y / A$ detection. The enzyme xilose isomerase activity was confirmed by the red clorofenol test. It is possible to regenerate sweet orange transgenic plants using the positive select system based on xylA gene, of 3 sweer orange varieties Hamlin, Valencia and Natal, with a genetic transformation efficiency of $1-3 \%$. 


\section{INTRODUÇÃO}

Dentre as fruteiras, as frutas cítricas são as mais produzidas no mundo, e em 2002 o volume total foi de, aproximadamente, 103 milhões de toneladas, sendo que Brasil e Estados Unidos responsáveis por quase metade dessa produção (FAO, 2003). A produção brasileira, atualmente ultrapassa 20 milhões de toneladas (FAO, 2003), tendo como principal pólo produtor o Estado de São Paulo, com quase $80 \%$ da produção brasileira.

Segundo a Secretaria de Agricultura e Abastecimento do Governo de São Paulo (SAA/SP, 2003) o Brasil é também o maior produtor e exportador mundial de suco de laranja concentrado congelado, com $74,6 \%$ das vendas no comércio internacional. Essa liderança competitiva deriva diretamente da consistência da produção e logística, que tem permitido qualidade e produtividade superiores aos demais concorrentes.

Se o Brasil produz $29 \%$ da laranja mundial, isoladamente São Paulo produz $21 \%$, o que corresponde a $78 \%$ da laranja brasileira, ou seja, São Paulo detém o maior pomar citrícola do mundo. A citricultura paulista é formada por 652,6 mil hectares de laranja com 211,6 milhões de pés, que em 2002 produziram 376 milhões de caixas de 40,8kg (SAA/SP, 2003). Essa pungente citricultura está quase que totalmente apoiada sobre o limão 'Cravo', sendo as laranjas 'Pêra', 'Valência' e 'Natal' as principais variedades copas utilizadas (Salva, 2001).

Segundo Neves \& Boteon (1998), as indústrias de suco concentrado de laranja para exportação comercializam, anualmente, cerca de $85 \%$ da produção paulista. O Estado de São Paulo é responsável por 98\% da produção total de 
suco concentrado. Além da importância econômica, a citricultura paulista também tem uma grande função social, pois as atividades da cadeia produtiva de citros empregam cerca de 300 mil pessoas, direta ou indiretamente, no Brasil (Neves \& Boteon, 1998).

A cultura dos citros está sujeita a um grande número de doenças, causadas por fungos, bactérias, vírus, viróides e ainda de causas desconhecidas (Timmer, 2001). Dentre as doenças causadas por bactérias duas são extremamente graves no país, o cancro cítrico (Xanthomonas axonopodis) e a clorose variegada dos citros - CVC (Xylella fastidiosa) (Feichtenberg, 1998).

Doenças como Cancro Cítrico e Clorose Variegada (amarelinho) do Citros tem sido objeto de ação direta do Governo de São Paulo visando preservar o inestimável patrimônio representado pelos pomares cítricos que, são fontes estratégicas de emprego e renda na economia estadual.

Atualmente, uma nova doença, denominada Morte Súbita dos Citros vem afetando plantas enxertadas sobre limão 'Cravo', o que vem a ser mais um agravante para a citricultura brasileira, que está fundamentada neste porta-enxerto (Müller \& De Negri, 2001).

Devido as plantas cítricas serem contituídas de um porta-enxerto e uma copa, o melhoramento genético dos citros é dividido em: melhoramento para as variedades porta-enxertos e para a variedade copa (Pompeu Junior, 1991). O melhoramento genético das plantas cítricas, pelos métodos tradicionais, utilizados no melhoramento genético vegetal, é dificultado por uma série de características da biologia de reprodução da espécie, como esterilidade de pólen e óvulo, autoincompatibilidade, poliembrionia (Gmitter et al., 1992; Ollitrault \& Luro, 1995), além da juvenilidade e da falta de conhecimento da natureza genética e do modo de herança das principais características de importância agronômica para a cultura. A utilização de técnicas modernas de biotecnologia, como a cultura de tecidos, a manipulação genética e a biologia molecular, têm se mostrado atrativas para o melhoramento genético de citros, pois podem colaborar para superar as dificuldades inerentes da cultura, permitindo o desenvolvimento de novas 
variedades, principalmente por hibridação somática e transformação genética. 0 desenvolvimento e a otimização de protocolos eficientes para transferência de DNA e produção de plantas transgênicas, oferece grandes vantagens para programas de melhoramento de variedades copa e porta-enxerto de citros, permitindo a introdução de genes específicos em variedades já cultivadas.

O objetivo deste trabalho foi avaliar a eficiência do gene de seleção xylA na transformação genética de variedades de laranja doce (Citrus sinensis). 


\section{REVISÃO DE LITERATURA}

\subsection{Citricultura no Brasil}

A origem das espécies do gênero Citrus tem sido tema de muita especulação e discussão. Em 1954, Tanaka concluiu, em seus estudos, que o centro de origem se situava ao noroeste da Índia e ao norte de Burma. Mais tarde, outros pesquisadores afirmaram que a região de origem dos citros é o continente asiático, estendendo-se do centro da China ao Japão e do leste da Índia à Nova Guiné, Austrália e África Tropical (Scora, 1975; Soost \& Cameron, 1975; Swingle \& Reece, 1967). Acredita-se, também, que Yunnan, na China, desempenhe um papel importante na origem de espécies contemporâneas de Citrus (Gmitter Junior \& Hu, 1990).

A família Rutaceae compreende 33 gêneros, três deles com importância comercial: Citrus, Fortunella e Poncirus, sendo nativos do continente asiático (Swingle \& Reece, 1967).

A cultura do citros possui grande potencial econômico no âmbito nacional e internacional. No Brasil pode ser caracterizada como uma das mais típicas atividades agro-industriais. Nas últimas décadas, o país vem liderando a produção mundial de citros, sendo que na safra 2001/2002 foram produzidas cerca de 20,251 milhões de toneladas de laranja, seguido pelos Estados Unidos, com produção de 14,865 milhões de toneladas (FAO, 2003). No panorama mundial, esta situação representa a má distribuição do plantio de citros no globo, onde apenas dois países detêm mais da metade da produção 
mundial (FNP consultoria e comércio, 2003). O Brasil produz $29 \%$ da laranja mundial, isoladamente São Paulo produz $21 \%$, o que corresponde a $78 \%$ da laranja brasileira, ou seja, São Paulo detém o maior pomar citrícola do mundo. As boas condições climáticas do Estado de São Paulo, associadas ao uso de diferentes cultivares, permitiram à indústria local estender as suas operações por um período superior a 9 meses no ano (Viégas \& Guimarães, 1991), enquanto nos Estados Unidos e no México, concorrentes diretos do Brasil, o período de produção é próximo a 6 meses, devido ao menor número de cultivares plantados e às condições climáticas (clima frio, sujeito à geadas) (Neves, 1996).

Apesar do impacto na economia brasileira, a citricultura passa por muitos problemas, na maioria das vezes relacionados à ocorrência de doenças. A maior ameaça ocorreu em 1937 com o aparecimento do vírus da tristeza, que praticamente eliminou 10 milhões de plantas enxertadas em laranjeira 'Azeda', atrasando o desenvolvimento da citricultura brasileira em uma dezena de anos. Outro problema foi a exocorte, surgido em conseqüência da solução encontrada para a tristeza, mas foi solucionado com a adoção do emprego dos clones nucelares. Em 1957, surge o cancro cítrico, trazido do Japão para o Estado de São Paulo, e mais uma vez a citricultura brasileira teve perdas significativas. No ano de 1987, surge uma nova doença denominada de clorose variegada dos citros (CVC), causada pela bactéria Xylella fastidiosa, que afetou a produção citrícola e exigiu grande atenção dos pesquisadores. Em 1999, foi identificada em pomares do sul do Triângulo Mineiro, uma nova doença, atualmente denominada de morte súbita dos citros (MSC), de causa ainda desconhecida, afetando pomares de laranjeira 'Valência' enxertada sobre limoeiro 'Cravo', causando a morte precoce das plantas. Atualmente, a doença já foi constatada em 19 municípios do sul do Triângulo Mineiro e no norte do Estado de São Paulo (Fundecitrus, 2003).

O uso adequado de um porta-enxerto pode propiciar frutos de melhor qualidade, que atendam às exigências internacionais para exportação de frutas 
frescas e ao mesmo tempo propiciem frutos com melhor qualidade para a indústrias processadoras de frutas, como atributos de tamanho e quantidade de sólidos solúveis. Uma outra razão para a utilização de porta-enxertos na citricultura, é que estes podem propiciar a produção de frutos em uma época em que geralmente os preços no mercado interno são melhores. As principais vantagens dos porta-enxertos são: redução da juvenilidade, compatibilidade, resistência a doenças, resistência a seca e qualidade de frutos. Os portaenxertos utilizados atualmente são: Limão 'Cravo', Tangerina 'Cleópatra', Citrumelo 'Swingle', Tangerina 'Sunki', 'Trifoliata', Limão 'Volkameriano'. Com relação às variedades copas, a escolha de uma variedade ideal, leva-se em consideração várias características como: época de produção, destino da produção, produtividade e qualidade dos frutos. As variedades copas mais utilizadas são 'Hamlin', 'Pêra', 'Valência', 'Natal'.

\subsection{Transformação genética de plantas}

A transformação genética pode ser definida como a introdução controlada de ácidos nucléicos em um genoma receptor (Brasileiro \& Dusi, 1999). É uma técnica de transferência não sexuada de genes para plantas. Na transformação o processo é mais controlado, onde apenas um fragmento definido de ácido nucléico (DNA) é introduzido no genoma do hospedeiro, ou genoma receptor, devendo ser a ele integrado (Brasileiro \& Dusi, 1999).

$\mathrm{O}$ desenvolvimento e a aplicação de uma metodologia eficiente para a transferência de DNA exógeno, com o objetivo de produzir plantas transgênicas, oferece vantagens ao melhoramento de variedades copa e portaenxerto de citros, pela possibilidade de se introduzir características específicas, mantendo-se as características originais da variedade e evitando-se a transferência de características deletérias ou desfavoráveis (Grosser, 1992).

Para o desenvolvimento de plantas transgênicas é essencial que se tenha disponibilidade de um sistema de cultura de tecidos que permita a 
regeneração de plantas e de um sistema de transformação genética que possibilite a introdução de genes com eficiência. A transferência de genes na transformação genética pode ser direta ou indireta. A transferência indireta é aquela que utiliza um vetor para intermediar a transformação, como Agrobacterium tumefaciens ou Agrobacterium rhizogenes. A transferência direta é baseada em métodos físicos ou químicos, onde destacam-se aceleração de partículas (biobalística) e eletroporação.

Agrobacterium tumefaciens e Agrobacterium rhizogenes, são bactérias pertencentes ao gênero Agrobacterium, família Rhizobiaceae. São fitopatógenos de solo que causam doença em dicotiledôneas, conhecidas como galha da coroa ou raiz em cabeleira, respectivamente. Essas bactérias tem a capacidade de infectar a maioria das dicotiledôneas e ambas as doenças são economicamente importantes, especialmente em plantas perenes em regiões de clima temperado. Os principais determinantes genéticos da patogenicidade deste gênero são os plasmídeos Ri (root inducing) de $A$. rhizogenes e $\mathrm{Ti}$ (tumour inducing) de A. tumefaciens. Durante o processo de patogênese, a bactéria tem a capacidade de transferir uma região determinada desses grandes plasmídeos, o T-DNA (transferred DNA), para o núcleo da célula vegetal onde é estavelmente integrado, transcrito e traduzido (Vieira \& Quecini, 2001).

O T-DNA carrega genes que codificam precursores de hormônios vegetais e de enzimas responsáveis pela condensacão de aminoácidos e cetoácidos ou açúcares em opinas chamados oncogenes. Os precursores de fitormônios produzidos pelas células transformadas levam a um desbalanço hormonal na planta promovendo a multiplicação celular desordenada que origina o tumor ou as raízes em cabeleira. As células vegetais e outros microrganismos do solo não têm a capacidade de catabolisar as opinas, funcionando com fonte exclusiva de carbono e nitrogênio e criando um nicho biológico altamente favorável para o desenvolvimento da Agrobacterium (Oger \& Cols, 1997). As características moleculares das opinas, sua síntese e catálise 
e suas funções como mediadoras químicas do parasitismo foram intensamente estudadas (Dessaux \& Cols, 1993).

Os plasmídeos patogênicos são caracterizados por ter genes para a produção de opinas, que determinam o tipo de opina que a célula vegetal irá produzir e que será degradado pela linhagem bacteriana causadora da doença. A caracterização da relação específica entre a bactéria e a natureza química das opinas detectadas nas células transformadas da planta são a base deste processo patogênico.

A transformação de plantas requer três componentes genéticos do Agrobacterium: i) o T-DNA que possui nas extremidades repetições de $25 \mathrm{pb}$ chamadas de bordas do T-DNA; ii) a região vir (virulência), compreendendo 35 $\mathrm{kb}$ do plasmídeo Ti/Ri e composta de sete locos principais vir $A$, vir $\mathrm{B}$, vir $\mathrm{C}$, vir $D$, vir $E$, vir $\mathrm{G}$, vir $\mathrm{H}$, e iii) os genes cromossomais de virulência chv (chromosomal virulence) (Vieira \& Quecini, 2001).

O processo de transferência pode ser dividido em duas etapas principais: uma etapa bacteriana e uma etapa eucariótica que ocorre na célula vegetal (Zupan \& Zambryski, 1995). A etapa bacteriana inclui a produção e exportação de um vetor funcional contendo a informação genética do T-DNA (Tinland, 1996). A etapa eucariótica inclui o reconhecimento entre a Agrobacterium e a célula hospedeira, a transdução de sinais vegetais de patogênese e a ativação dos genes vir (Sheng \& Citovsky, 1996). Uma vez que o segmento a ser transferido é definido por suas bordas, a região codante do T-DNA do tipo selvagem pode ser substituída por qualquer outra sequência de DNA sem que sua transferência da Agrobacterium para a planta seja prejudicada. A substituição dos oncogenes por genes de interesse, flanqueados pelas bordas do T-DNA, fornece um sistema eficiente de obtenção de plantas transgênicas.

A presença de ferimentos faz com que células vegetais liberem secreções líquidas contendo compostos fenólicos de baixo peso molecular, açúcares e precursores de flavonóides. Essas moléculas não são detectadas ou são detectadas em quantidades muito baixas em plantas não feridas. Outras 
interações planta-microrganismo podem ser iniciadas por compostos fenólicos específicos exudados pelas plantas, como por exemplo luteolina e chalcona induzindo genes de nodulação de Rhizobium na associação simbiótica com leguminosas. Ferimentos pequenos levam à liberação de monossacarídeos e esses podem auxiliar na ativação de vias de sinalização de ferimentos mediadas por compostos fenólicos provocando sua liberação subsequente. $\mathrm{Na}$ ausência de compostos fenólicos, monossacarídeos também podem induzir o operon vir (Vieira \& Quecini, 2001).

\subsection{Transformação genética de citros}

Recentemente trabalhos de transformação genética de citrus têm sido feitos pelo método indireto utilizando Agrobacterium. A transformação genética mediada por Agrobacterium tumefaciens envolve várias etapas, como a inoculação da bactéria nos explantes, o co-cultivo em meio de regeneração e a seleção e identificação das células transformadas. Para a seleção das células transformadas, normalmente são utilizados genes que conferem resistência a antibióticos, herbicidas ou genes de seleção positiva como o gene manA.

A primeira descrição de transformação genética em citros foi feita por Kobayashi \& Uchimiya (1989) utilizando a técnica de absorção direta de DNA, por meio de PEG, em protoplastos. Desde então, outros protocolos têm sido descritos com a utilização de co-cultivo de Agrobacterium tumefaciens com segmento internodal de plantas cultivadas in vitro ou em casa-de-vegetação, ou com segmento de epicótilo.

Moore et al. (1992) desenvolveram um sistema de transformação para Citrus, mediado por Agrobacterium, que foi usado para produzir plantas transgênicas de citrange 'Carrizo'. Com este método, segmentos internodais de ramos foram inoculados com uma linhagem 'desarmada' de Agrobacterium contendo um plasmídeo vetor com genes codificando para nptll e $\beta$ glucuronidase (GUS). Segmentos foram cultivados em meio de regeneração, selecionados na presença do antibiótico canamicina e tratados com o antibiótico 
cefotaxime para inibir o crescimento da Agrobacterium, e as plantas foram regeneradas via organogênese.

Trabalhos recentes comprovaram uma maior eficiência na indução da organogênese dos citros com o uso de BAP (Benzilaminapurina), na concentração de $1 \mathrm{mg} \mathrm{L}^{-1}$. O fotoperíodo também foi avaliado sendo que o uso de $16 \mathrm{~h}$ de luz e $8 \mathrm{~h}$ de escuro, com explantes de 28 dias de idade permitiu a obtenção do maior número de gemas adventícias (Costa et al., 2003).

Os explantes que são mais utilizados na transformação genética de citros são segmentos de epicótilo (Cervera et al., 2000a; Yang et al., 2000; Mendes et al., 2002, Molinari et al., 2003) e segmentos internodais (Peña et al., 1995b, 1997; Gutiérrez-E. et al., 1997; Pérez-Molphe-Balch \& Ochoa-Alejo, 1998; Boscariol et al., 2003, Molinari et al., 2003), coletados de tecido juvenil.

Os métodos para transformação genética em citros utilizam em sua maioria tecido juvenil, porém, as características só poderão ser avaliadas quando as plantas deixarem a fase juvenil, o que poderá demorar vários anos no caso de laranja doce (Cervera et al., 1998a). Cervera et al. (1998a) obtiveram plantas transformadas de laranja doce a partir de tecido maduro utilizando um período de co-cultivo de 3 dias. Estas plantas obtidas em condições de casa-de-vegetação apresentaram florescimento após 14 meses. Trabalhos realizados por Almeida et al. (2003) também conseguiram regenerar plantas adultas de laranja doce geneticamente transformadas, porém usando um dia de co-cultivo com a bactéria.

Várias estirpes de Agrobacterium têm sido testadas em citros, dentre elas, EHA 101 e EHA 105 (Peña et al., 1995a; 1995b; 1997; Gutiérrez-E. et al., 1997; Bond \& Roose, 1998; Molinari et al., 2003), mostraram melhores resultados. A estirpe A281 de Agrobacterium tumefaciens é capaz não só de apenas transformar citros eficientemente, mas é ainda supervirulenta em muitos genótipos de citros (Cervera et al.,1998c). A supervirulência do A281em muitas plantas, tem sido atribuída à alta expressão dos genes vir após a indução (Navarro et al., 2002). A freqüência de regeneração de plantas transformadas 
proveniente de sistemas baseados em Agrobacterium tumefaciens tem sido baixa. Na tentativa de aumentar a eficiência de transformação genética em citros, vários trabalhos foram realizados utilizando diferentes tipos de explantes: segmento internodal (Moore et al., 1992; Peña et al., 1995; Pérez-Molphe-Balch \& Ochoa-Alejo, 1998; Cervera et al., 1998a; Molinari et al., 2003), células em suspensão (Hidaka et al., 1990), protoplastos (Fleming et al., 2000) e segmentos de epicótilo (Moore et al., 1992; Kaneyoshi et al., 1994; Peña et al., 1997; Cervera et al., 1998b; 2000; Bond \& Roose, 1998, Yang et al., 2000, Boscariol et al., 2003). A eficiência de transformação obtida em segmentos internodais de citrange 'Carrizo' foi de $2 \%$ (Moore et al. 1992), em laranja doce 7,9\% (Peña et al., 1995a) e em lima mexicana de 6,7\% (Peña et al., 1997), em Citrumelo Swingle x Poncirus trifoliata de 8,6\% (Molinari et al., 2003). Além da baixa eficiência de regeneração de plantas transformadas, Moore et al. (1992) relatam sérias dificuldades no enraizamento das plantas obtidas. Para solucionar o problemas de enraizamento das plantas in vitro foi feita a enxertia in vitro (microenxertia) de ápices meristemáticos sobre porta-enxertos vigorosos (Peña et al., 1995a; 1995b; 1997), o que tem aumentado o número final de plantas transformadas.

Genes de interesse agronômico já foram introduzidos na cultura do citros como o gene de tolerância a sais HAL2 (Cervera et al., 2000b) em citrange Carrizo, e implicou mecanismos de tolerância a sais (Murguía et al., 1995), e em grapefruit o gene GNA que confere resistência contra afídeos (Yang et al., 2000). Peña et al. (2001) demostraram plantas de citrange 'Carrizo' expessando os genes LEAFY e APETALA1 de Arabidopsis, que tiveram o período de juvenilidade diminuídos, florescendo já no primeiro ano de cultivo. O gene da capa protéica do vírus da tristeza que promove tolerância ou resistência ao vírus da tristeza dos citros foi introduzido em laranja 'Azeda' (Citrus aurantium), lima ácida Key (C. aurantifolia) (Gutiérrez-E. et al., 1997), em lima ácida Mexicana (C. aurantifolia) (Domíngues et al., 2000) e em pomelo (C. paradisi) (Febres et al., 2003). Foram introduzidas também versões codificadas e não 
codificadas da proteína p25 do vírus da tristeza dos citros (CTV) em lima que é muito sensível a CTV, para avaliar a resistência. Mais de 40 linhas transgênicas expressando o gene da proteína para o vírus já foram produzidas (Domínguez et al., 2000). Esta é a primeira demonstração de resistência em plantas transgênicas contra um membro de Closterovirus. Kobayashi et al. (2001) obtiveram 8 plantas transformadas, utilizando segmentos de 1-2 $\mathrm{mm}$ de espessura de plantas maduras de laranja 'Pera' que foram transformados via $A$. tumefaciens com o gene sarco, da sarcotoxina, um peptídeo antibacteriano isolado de Sarcophaga peregrina que é altamente eficiente na inibição do crescimento de Xanthomonas axonopodis pv. citri, causadora do cancro cítrico. Segundo os autores, a eficiência do processo mostrou-se elevada quando comparada a experimentos anteriores, apesar de apenas $20 \%$ das plântulas recuperadas serem transformantes. Também foi produzido com sucesso plantas de laranja doce 'Pineapple' transgênicas com um gene que compreende a região de codificação do gene $\mathrm{P} 23$, que codifica uma proteína 23-kDa relacionada à patogênese induzida em plantas de tomate quando são infectados com o vírus da exocorte dos citros (Rodrigo et al., 1993)

Os genes de seleção mais utilizados são genes que conferem resistência a antibióticos, como os que codificam para as enzimas neomicina fosfotransferase II (npt/l) e higromicina fosfotransferase (hph), que conferem resistência aos antibióticos canamicina e higromicina, respectivamente, ou a herbicidas como o gene bar, que codifica a enzima fosfinotricina acetiltransferase, que confere resistência ao herbicida fosfinotricina (Brasileiro \& Dusi, 1999; Bailey \& Kaeppler, 2001), permitindo que as células transformadas se desenvolvam em meio de cultura contendo o composto tóxico (Haldrup et al., 1998a).

O uso de antibióticos e/ou herbicidas como agentes de seleção em transformação genética de espécies vegetais tem sofrido críticas do público em geral, devido a falta de conhecimento do impacto destes genes no ambiente e na saúde humana (Wang et al., 2000), sendo que a União Européia proibiu a 
comercialização de alimentos transgênicos com antibióticos até 2005 (Navarro et al., 2002) estimulando assim o desenvolvimento de sistemas alternativos de seleção. Com isso, torna-se muito importante avaliar a eficiência de sistemas alternativos de seleção para serem utilizados na transformação genética de citros, como os sistemas baseados no uso de agentes não-metabolizáveis (Haldrup et al., 1998; Joersbo \& Okkels, 1996), que empregam os genes $x y / A$ (Haldrup et al., 1998, 2001), manA (Negrotto et al., 2000; Wright et al., 2001).

Dentre os métodos alternativos de seleção de células transgênicas, está o uso de genes que conferem capacidade às células de se desenvolver na presença de substratos que normalmente não são metabolizáveis (Bailey \& Kaeppler, 2001), como os genes manA e xylA, que permitem o desenvolvimento das células em meios de cultura suplementados com os açúcares manose e xilose como fonte de carbono, respectivamente. O gene manA codifica a enzima fosfomanose isomerase (PMI), que catalisa a interconversão reversível da manose 6-fosfato em frutose 6-fosfato (Privalle et al., 1999). Este gene não está presente na maioria das espécies vegetais, e a expressão do PMI permite que as células utilizem a manose como fonte de carbono. Normalmente, a manose é absorvida e convertida em manose-6-fosfato pela ação da enzima hexoquinase. No entanto, a manose 6-fosfato não é utilizada pelas células vegetais pela deficiência na enzima fosfomanose isomerase, necessária para a conversão em frutose-6-fosfato. O acúmulo de manose-6-fosfato nas células inibe a ação da enzima fosfoglucose isomerase bloqueando a glicólise (Negrotto et al., 2000). Assim, células transformadas contendo o gene PMI, teriam condições de converter a manose-6-fosfato em frutose-6-fosfato, a qual pode ser incorporada à glicólise.

O gene $x y I A$ codifica a enzima xilose isomerase, que catalisa a isomerização reversível de D-xilose para D-xilulose (Haldrup et al., 1998a), que entra na via da pentose-fosfato, após ser convertida em xilulose-5-fosfato, permitindo então que células vegetais se desenvolvam em meio de cultura suplementado com o açúcar xilose como fonte de carbono. Este gene é 
encontrado em um grande número de procariotos, tendo sido isolado de Thermoanaerobacterium thermosulfurogenes (Haldrup et al., 1998a) e de Streptomyces rubiginosus (Haldrup et al., 1998b), mas na maioria das espécies vegetais ele é fracamente expresso (Haldrup et al., 2001). De maneira diferente dos sistemas tradicionais de transformação genética, utilizando genes de resistência antibióticos e herbicidas, que matam as células não-transformadas, as células transformadas com estes genes adquirem uma vantagem de crescimento no meio de cultura contendo o agente de seleção (Privalle et al., 1999). Este processo é denominado seleção positiva (Haldrup et al., 1998b; 2001) onde células não transgênicas tem seu desenvolvimento paralisado, porém permanecem vivas, não expondo as células transformadas a compostos tóxicos liberados por células mortas, que podem afetar seu desenvolvimento (Haldrup et al., 1998b).

O gene $x y \mid A$ foi utilizado para transformação genética, via Agrobacterium, de segmento internodal de batata, discos de folha de tabaco e segmento de hipocótilo de tomate, sendo que para as espécies batata e tomate foi obtida uma maior eficiência de transformação em comparação com resultados obtidos com a utilização do antibiótico canamicina (Haldrup et al., 2001). Não existem relatos na literatura da utilização deste gene de seleção em transformação genética de citros. O gene de seleção manA tem sido utilizado para transformação genética de variedades de laranja doce, tendo sido possível a obtenção de plantas transgênicas das variedades 'Pera', 'Hamlin', 'Natal' e 'Valencia' (Boscariol et al., 2003). 


\section{MATERIAL E MÉTODOS}

O projeto de pesquisa foi desenvolvido no Laboratório de Biotecnologia Vegetal, do CENA/USP. O sistema de transferência de genes selecionado foi com a utilização de Agrobacterium tumefasciens, já que resultados obtidos anteriormente pelo Laboratório, mostraram a eficiência do método. Foi dada ênfase aos genótipos de laranja doce (C. sinensis), como as variedades 'Valência', 'Pêra',' Natal' e 'Hamlin'.

\subsection{Material vegetal}

Sementes poliembriônicas, coletadas de frutos maduros foram germinadas in vitro, em tubos de ensaio $(25 \times 150 \mathrm{~mm})$, contendo $10 \mathrm{~mL}$ de meio de cultura MS (Murashige \& Skoog, 1962), incubados em ausência de luz, à temperatura de $27^{\circ} \mathrm{C}$, por um período de 2-3 semanas. Plântulas, com aproximadamente $15 \mathrm{~cm}$ de altura, foram transferidas para condições de fotoperíodo de 16 horas de luz, onde permaneceram por um período de 7-10 dias. Os explantes, segmentos de epicótilo (1 $\mathrm{cm}$ de comprimento), foram coletados destas plântulas e mantidos em meio de cultura MS líquido até o momento da inoculação com Agrobacterium.

\subsection{Avaliação da sensibilidade dos explantes a xilose}

Os explantes foram incubados em meio de cultura EME (Grosser \& Gmitter, 1990), suplementado com $1 \mathrm{mg} \cdot \mathrm{L}^{-1}$ de Benzilaminopurina (BAP) e diferentes combinações de sacarose e xilose como fonte de carbono. Foram 
testadas as concentrações de $73 \mathrm{mM}\left(25 \mathrm{~g} \cdot \mathrm{L}^{-1}\right)$ de sacarose e as combinações de: $6 \mathrm{mM}\left(2 \mathrm{~g} . \mathrm{L}^{-1}\right)$ de sacarose com, $33 \mathrm{mM}, 66 \mathrm{mM}, 83 \mathrm{mM}, 99 \mathrm{mM}$ e $99 \mathrm{mM}$ de xilose isolado. Foram realizadas 5 repeticões, sendo cada repetição constituída de uma placa de petri com 20 explantes. A incubação foi realizada sob fotoperíodo de 16 horas de luz, à temperatura de $27^{\circ} \mathrm{C}$. A avaliação foi realizada após 4 semanas de incubação, determinando-se o número de explantes que apresentaram o desenvolvimento de gemas adventícias.

\subsection{Vetor de expressão}

O plasmídeo contendo o gene de seleção xylA foi introduzido na estirpe de Agrobacterium EHA-101. O gene utilizado nesse trabalho tem a seguinte construção: pNOV 1457 contendo o gene xylA, dirigido pelo promotor Cestrium Yellow Leaf Curling Vírus (CMPS), com o terminador NOS (Figura 1). Esse plasmídeo foi fornecido pela Syngenta.

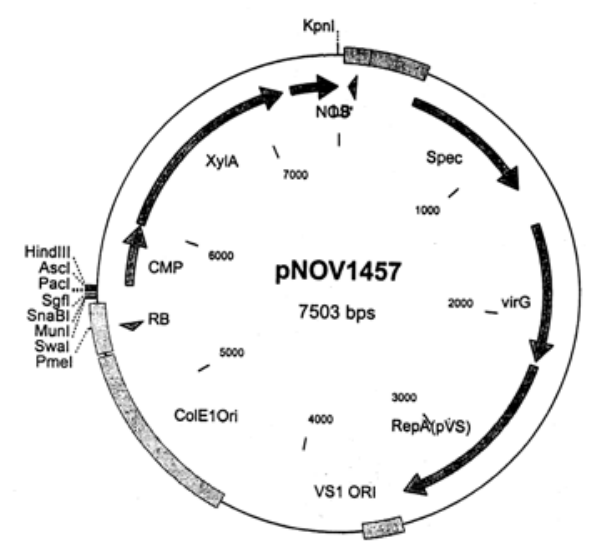

Figura 1 - Plasmídeo contendo o gene xylA, que foi introduzido em Agrobacterium tumefasciens EHA 101 


\subsection{Cultura de Manutenção dos Isolados de Agrobacterium}

Os experimentos foram realizados com a estirpe EHA 101 de Agrobacterium tumefaciens, contendo o plasmídeo pNOV1457. Os isolados da bactéria foram mantidos em meio de cultura YEP (extrato de levedura $10 \mathrm{~g} . \mathrm{L}^{-1}$; $\mathrm{NaCl} 5 \mathrm{~g} . \mathrm{L}^{-1}$; peptona $\left.10 \mathrm{~g} \cdot \mathrm{L}^{-1}\right)$, suplementado com os antibióticos específicos (ácido nalidíxico, canamicina e streptomicina) para a estirpe. Para os experimentos, uma colônia isolada da bactéria foi transferida para o meio de cultura YEP líquido, suplementado com os antibióticos específicos, e cultivada por 16 horas, em ausência de luz, sob agitação de $180 \mathrm{rpm}$ a $28^{\circ} \mathrm{C}$. Após a incubação, a suspensão bacteriana foi centrifugada (4800 rpm; $20 \mathrm{~min}$ ) e resuspendida em meio de cultura MS, na concentração de $5 \times 10^{8}$ ufc. $\mathrm{mL}^{-1}$.

\subsection{Inoculação com Agrobacterium}

Segmentos de epicótilo foram incubados, por um período de $20 \mathrm{~min}$, com a suspensão bacteriana. Após a inoculação, os segmentos foram secos em papel toalha estéril, e incubados em placa de petri $(100 \times 15 \mathrm{~mm})$ contendo o meio de cultura EME + BAP $\left(1 \mathrm{mg} \cdot \mathrm{L}^{-1}\right)$, em ausência de luz, à temperatura de $24^{\circ} \mathrm{C}$, por um período de 3 dias, para o co-cultivo.

\subsection{Seleção e regeneração de plantas}

Após o co-cultivo, os explantes foram transferidos para meio de cultura de seleção, constituído do meio de cultura EME + BAP $\left(1 \mathrm{mg} \cdot \mathrm{L}^{-1}\right)+$ cefotaxime $\left(500 \mathrm{mg} \cdot \mathrm{L}^{-1}\right)+$ xilose $99 \mathrm{mM}\left(15 \mathrm{~g} \cdot \mathrm{L}^{-1}\right)$. A concentração de xilose utilizada para seleção foi determinada com experimentação, testando-se diferentes combinações de xilose e sacarose. Os explantes foram transferidos para meio de cultura fresco em intervalo de 2 semanas. Os brotos formados foram microenxertados in vitro. 


\subsection{Análise de DNA}

A transformação genética foi confirmada pela detecção do gene xylA nas plantas regeneradas. A extração do DNA foi feita pelo método de Dellaporta et al. (1983) e as reações de PCR foram conduzidas em termociclador PTC-100 (MJ Research) utilizando-se "primers" específicos para a detecção do gene xylA 5'-ACATCCGCTTCGCCATCGAG-3' e 5'ATGCCGTTCTGGCCGTTGAG-3'. As reações de PCR foram com 1 ciclo de $1 \mathrm{~min} / 94{ }^{\circ} \mathrm{C}$ e 30 ciclos de $30 \mathrm{~s} / 94^{\circ} \mathrm{C}, 30$ $\mathrm{s} / 60^{\circ} \mathrm{C}$ e $45 \mathrm{~s} / 72^{\circ} \mathrm{C}$.

\subsection{Microenxertia e aclimatização}

Os brotos desenvolvidos e identificados como transgênicos por PCR, foram microenxertados em plântulas de citrange 'Carrizo' germinadas in vitro (Peña et al., 1995b). Para a microenxertia, foi removido o ápice meristemático das brotações, os quais foram microenxertados numa incisão em forma de $T$ invertido, realizada na plântula do porta-enxerto. Estas plantas foram incubadas sob fotoperíodo de $16-\mathrm{h}$, a $28{ }^{\circ} \mathrm{C}$, até o desenvolvimento da plântula completa. Plântulas com aproximadamente 5-7 cm de altura, contendo 5-6 folhas, foram transferidas para vasos contendo substrato estéril, e aclimatizadas para condições de casa-de-vegetação.

\subsection{Determinação da atividade da enzima xilose isomerase}

Folhas de plantas transformadas $\left(\mathrm{PCR}^{+}\right)$foram avaliadas para a atividade da enzima xilose isomerase, pelo teste com o indicador de $\mathrm{pH}$ clorofenol vermelho (Clororofenol Red - CR) de acordo com Wright et al. (2001). Segmentos de folhas ( 4 por planta) foram incubados em meio de cultura MS contendo xilose $+\mathrm{CR}$ e incubados a $27^{\circ} \mathrm{C}$, no escuro, por 3-4 dias. A alteração da coloração do meio de cultura para amarelo indica atividade da enzima, enquanto que a manutenção da coloração arroxeada indicam que não houve atividade enzimática. 


\section{RESULTADOS E DISCUSSÃO}

$\mathrm{Na}$ transformação genética de plantas apenas uma pequena parte das células tratadas tornam-se transgênicas, enquanto a maioria das células permanecem não transformadas (Joersbo \& Okkels, 1996; Haldrup et al., 1998). Assim, um trabalho de transformação genética de plantas exige um bom sistema para introdução de genes e também um sistema eficiente de seleção (Negrotto et al., 2000) que favoreça o desenvolvimento das células transgênicas. Esta seleção é feita pela inserção de genes que permitam que as células transformadas cresçam em meio de cultura seletivo, enquanto que as não transformadas morrem (Joersbo \& Okkels, 1996). Os genes de seleção mais utilizados são genes que conferem resistência a antibióticos, como os que codificam para as enzimas neomicina fosfotransferase II (nptl) e higromicina fosfotransferase ( $h p h)$, que conferem resistência aos antibióticos canamicina e higromicina, respectivamente, ou a herbicidas como o gene bar que codifica para a enzima fosfinotricina acetiltransferase, que confere resistência ao herbicida fosfinotricina (Brasileiro \& Dusi, 1999).

Recentemente, o uso de antibióticos e/ou herbicidas como agentes de seleção em transformação genética de espécies vegetais tem sofrido críticas do público em geral, devido a falta de conhecimento do impacto destes genes no ambiente e na saúde humana (Wang et al., 2000) estimulando o desenvolvimento de sistemas alternativos de seleção. Dentre os métodos alternativos de seleção de células transgênicas, está o uso de genes que conferem capacidade às células de se desenvolver na presença de substratos 
que normalmente não são metabolizáveis (Bailey \& Kaeppler, 2001), como os genes manA e xylA, que permitem o desenvolvimento das células em meios de cultura suplementados com os açúcares manose e xilose como fonte de carbono, respectivamente.

O gene $x y / A$ codifica a enzima xilose isomerase, que catalisa a isomerização reversível de D-xilose para D-xilulose (Haldrup et al., 1998a), que entra na via das pentoses-fosfato, após ser convertida em xilulose-5-fosfato, permitindo então que células vegetais se desenvolvam em meio de cultura suplementado com o açúcar xilose como fonte de carbono. Este gene é encontrado em um grande número de procariotos, tendo sido isolado de Thermoanaerobaclerium thermosulfurogenes (Haldrup et al., 1998a) e de Strepímyces rubíginosus (Haldrup et al., 1998b), mas na maioria das espécies vegetais ele é fracamente expresso (Haldrup et al., 2001). Tanto o gene manA como o gene $x y l A$ separam as células não-transformadas das transformadas dificultando o crescimento das nâo-transformadas pela falta de carboidratos. De maneira diferente dos sistemas tradicionais de transformação genética, utilizando genes de resistência a antibióticos ou herbicidas, que matam as células não-transformadas, as células transformadas com estes genes adquirem uma vantagem de crescimento no meio de cultura contendo o agente de seleção (Privalle et al., 1999). Este processo é denominado seleção positiva (Haldrup et al., 1998b; 2001) onde células não transgênicas tem seu desenvolvimento paralizado, porém permanecem vivas, não expondo as células transformadas a compostos tóxicos liberados por células mortas, que podem afetar seu desenvolvimento (Haldrup et al., 1998b).

A organogênese in vitro em citros ocorre quando explantes não meristemáticos como segmentos de epicótilo e internodal são cultivados em meio de cultura contendo sais, vitaminas, reguladores vegetais e sacarose como fonte de carbono (Peréz-Molphe-Balch \& Ochoa-Alejo, 1997; MoreiraDias et al., 2000; Almeida et al., 2003). A inibição da organogênese em segmentos de epicótilo de citros cultivados em meio de cultura suplementado 
com xilose, indica que os explantes não são capazes de utilizar este açúcar como fonte de carbono (Tabela 1). Este fato ocorre provavelmente devido a ausência de atividade endógena da enzima xilose isomerase nesta espécie. $O$ desenvolvimento de gemas adventícias nos explantes cultivados em meio de cultura suplementado com frutose ou glicose em porcentagens semelhantes ao uso de sacarose (Tabela1) indica que estes açucares também podem ser utilizados como fonte de carbono pelos esxplantes de citros.

Tabela 1. Desenvolvimento de gemas adventícias em segmentos de epicótilo de C. sinensis, var. 'Valência' e 'Hamlin', cultivadas em meio de cultura EME suplementado com diferentes fontes de carboidrato (73 $\mathrm{mM}$ )

\begin{tabular}{|c|c|c|c|}
\hline \multirow[t]{2}{*}{ Carboidrato } & \multicolumn{3}{|c|}{$\begin{array}{c}\mathrm{N}^{\circ} \text { de explantes responsivos } / \mathrm{N}^{\circ} \text { total de } \\
\text { explantes }{ }^{\mathrm{a}}(\%)\end{array}$} \\
\hline & Valência $^{b}$ & Hamlin $^{\mathrm{b}}$ & \\
\hline glucose & $13,4 / 20(63) a$ & $14,2 / 20(71) a$ & \\
\hline sacarose & $13,8 / 20(64) a$ & $15,0 / 20(75) a$ & \\
\hline frutose & $11,2 / 20(56) \quad b$ & $10,8 / 20(54)$ & $\mathrm{b}$ \\
\hline xilose & $0,2 / 20(1,0)$ & $1,4 / 20(9)$ & c \\
\hline
\end{tabular}

aexplantes com pelo menos uma gema adventícia.

${ }^{\mathrm{b}}$ cada valor representa a média de 5 repetições, com um total de100 explantes por tratamento. Médias com a mesma letra não diferem significativamente (Tukey 0,01 )

O açúcar xilose foi utilizado como agente de seleção em transformação genética de batata, tomate e tabaco, sendo que batata e tomate mostraram-se extremamente sensíveis a presença de xilose. A suplementação do meio de cultura apenas com xilose não permitiu o desenvolvimento de gemas adventícias nessas culturas, após a inoculação com Agrobacterium (Haldrup et al., 1998a). Assim, a fim de favorecer o desenvolvimento de brotos na transformação genética estas culturas foram cultivadas em meio de cultura 
suplementado com uma combinação de xilose e sacarose. Para o caso específico dos citros, foi possível verificar que suplementação do meio de cultura com uma combinação de sacarose e xilose favorece o desenvolvimento de gemas adventícias (Tabela 2) diminuindo o efeito tóxico do açúcar xilose. 0 aumento na concentração de xilose inibiu o desenvolvimento de gemas adventícias mesmo na presença de sacarose.

Tabela 2. Desenvolvimento de gemas adventícias em segmentos de epicótilo de C. sinensis, var. 'Valência' e 'Natal', cultivadas em meio de cultura EME suplementado com diferentes combinações de sacarose e xilose

'Valência'

xilose sacarose $\mathrm{N}^{\circ}$ de explantes com gemas/ $(\mathrm{mM}) \quad(\mathrm{mM}) \quad \mathrm{N}^{\circ}$ total explantes $(\%)$

$\mathrm{N}^{\circ}$ de explantes com gemas/

990

$83 \quad 06$

$66 \quad 06$

$33 \quad 06$

$0 \quad 73$

$\mathrm{N}^{\circ}$ total explantes (\%)

'Natal'

Cada valor representa a média de 5 repetições, com um total de100 explantes por tratamento. Médias com a mesma letra não diferem significativamente (Tukey 0,01 )

A Figura 2 mostra os resultados obtidos na transformação genética de $C$. sinensis utiiizando-se o sistema de seleção xylA/xilose. Após 30 dias da inoculação com Agrobacterium já era possível visualizar o desenvolvimento de gemas adventícias (Figuras 2a e 2b). A análise de PCR permitiu identificação de brotos contendo o gene xylA (Figura 2e) os quais foram microenxertados (Figura 2c) e aclimatizados para condições de casa-de-vegetação (Figura 2d). 
A transformação genética usando o sistema $x y / A / x i l o s e$ foi feita utilizando-se meio de cultura de seleção suplementado com xilose (99 mM, 15 $\mathrm{g} / \mathrm{L}$ ). Com base nos dados de sensibilidade dos explantes optou-se pelo uso do carboidrato xilose isolado, sem a combinação com sacarose, a fim de evitar o desenvolvimento de escapes. As Tabelas 3 e 4, mostram o número de plantas transgênicas obtidas para as variedades 'Pêra', 'Valência', 'Nata'l e 'Hamiln', em experimentos realizados sem e com a adição de acetoseringona no meio de cultura para co-cultivo, respectivamente. Mesmo utilizando-se apenas xilose para a seleção ainda ocorreu o desenvolvimento de plantas escapes.

Pela análise dos dados obtidos pode-se verificar que foram obtidas plantas transgênicas, utilizando-se o sistema $x y / A / x i l o s e$, de 3 variedades de laranja doce 'Hamlin', 'Valência' e 'Natal', com uma eficiência de transformação genética variando de 1 - 3\%, em função do experimento e da variedade (Tabelas 3 e 4). A eficiência de transformação genética de citros utilizando-se o antibiótico canamicina como agente de seleção varia de 0,52 - 55,2\% para citrange 'Carrizo' e híbridos relacionados (Moore et al, 1992; Kaneyoshi et al, 1994; Pena et al., 1995) e 10 - 20\% para lima Mexicana (Gutiérrez-E. et al., 1997) e 3,6\% para grapefruit (Yang et al., 2000). Para variedades de laranja doce são relatados os valores 7,6\% para laranja 'Pineapple' (Pena et al., 1995a) e 15\% para Hamlin (Mendes et al., 2002). Utilizando-se o sistema de seleção positiva PMI/manose, também com variedades de laranja doce Pêra, Valência, Natal e Hamlin a eficiência de transformação genética variou de $3-7,6 \%$ (Boscariol et al., 2003). 
Tabela 3. Regeneração de plantas e eficiência de transformação genética em segmentos de epicótilo de laranja doce, variedades 'Pêra', 'Valência', 'Natal' e 'Hamlin' usando o sistema de seleção xyla/xilose (xilose $99 \mathrm{mM}$, sem acetoseringona no co-cultivo

\begin{tabular}{ccc}
\hline $\begin{array}{c}\text { Variedade } \\
\text { No de plantas desenvolvidas/ } \\
N^{\circ} \text { te explantes }\end{array}$ & $\begin{array}{l}\mathrm{N}^{\circ} \text { de plantas } \mathrm{PCR}^{+} / \\
\text {Eficiência de transformação (\%) }\end{array}$ \\
\hline Pêra & $6 / 100$ & $0 / 0$ \\
Valência & $12 / 100$ & $2 / 2$ \\
Natal & $4 / 100$ & $1 / 1$ \\
Hamlin & $8 / 100$ & $2 / 2$ \\
\hline
\end{tabular}

Pela experiência de trabalho do Laboratório de Biotecnologia Vegetal, do CENA/USP, a eficiência de transformação genética da variedade Pêra, normalmente é mais baixa quando comparada com outras variedades de laranja doce. Utilizando-se o sistema $x y \mid A / x i l o s e$ não foi possível regenerar plantas transgênicas desta variedade. Provavelmente, isto se deve ao fato da maior resistência da variedade 'Pêra' à transformação genética e a menor

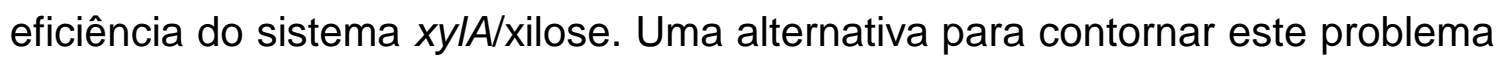
seria a utilização de um maior número de explantes no processo. 
Tabela 4. Regeneração de plantas e eficiência de transformação genética em segmentos de epicótilo de laranja doce, variedades Pêra, Valência, Natal e Hamlin usando o sistema de seleção xyla/xilose (xilose 99mM, com acetoseringona no co-cultivo)

\begin{tabular}{ccc}
\hline $\begin{array}{c}\text { Variedade } \\
\mathrm{N}^{\circ} \text { total de explantes }\end{array}$ & $\begin{array}{l}\mathrm{N}^{\circ} \text { de plantas } \mathrm{PCR}^{+} / \\
\text {Eficiência de transformação (\%) }\end{array}$ \\
\hline Pêra & $13 / 100$ & $0 / 0$ \\
Valência & $15 / 100$ & $3 / 3$ \\
Natal & $10 / 100$ & $1 / 1$ \\
Hamlin & $11 / 100$ & $2 / 2$ \\
\hline
\end{tabular}

Embora para Citrus sinensis a eficiência de transformação genética utilizando-se o sistema $x y / A / x i l o s e$ foi menor do que a eficiência obtida com sistemas tradicionais de seleção e pelo sistema PMI/manose, nas culturas de batata (Haldrup et al., 2001) fumo e tomate (Penna et al., 2002) a eficiência de transformação genética utilizando este sistema variou de 2,9 - 12\%, 13\% e 9\%, respectivamente, demonstrando a eficiência do método. A confirmação da expressão do gene $x y \mid A$ foi feita pela avaliação da atividade da enzima xilose isomerase no teste com o indicador de $\mathrm{pH}$ clorofenol vermelho (Figura 2f). Foi possível verificar que plantas $\mathrm{PCR}^{+}$foram capazes de absorver o açúcar xilose presente no meio de cultura alterando o $\mathrm{pH}$ e conseqüentemente a coloração do meio de cultura de violeta para amarelo alaranjado. As plantas não transformadas não metabolizaram o açúcar mantendo a coloração inicial do meio de cultura.

A eficiência de transformação genética de citrus utilizando-se este método de seleção pode ser melhorada modificando-se o protocolo de trabalho, variando-se parâmetros relacionados não só a cultura de tecidos, mas também com relação a construção do vetor de expressão. 

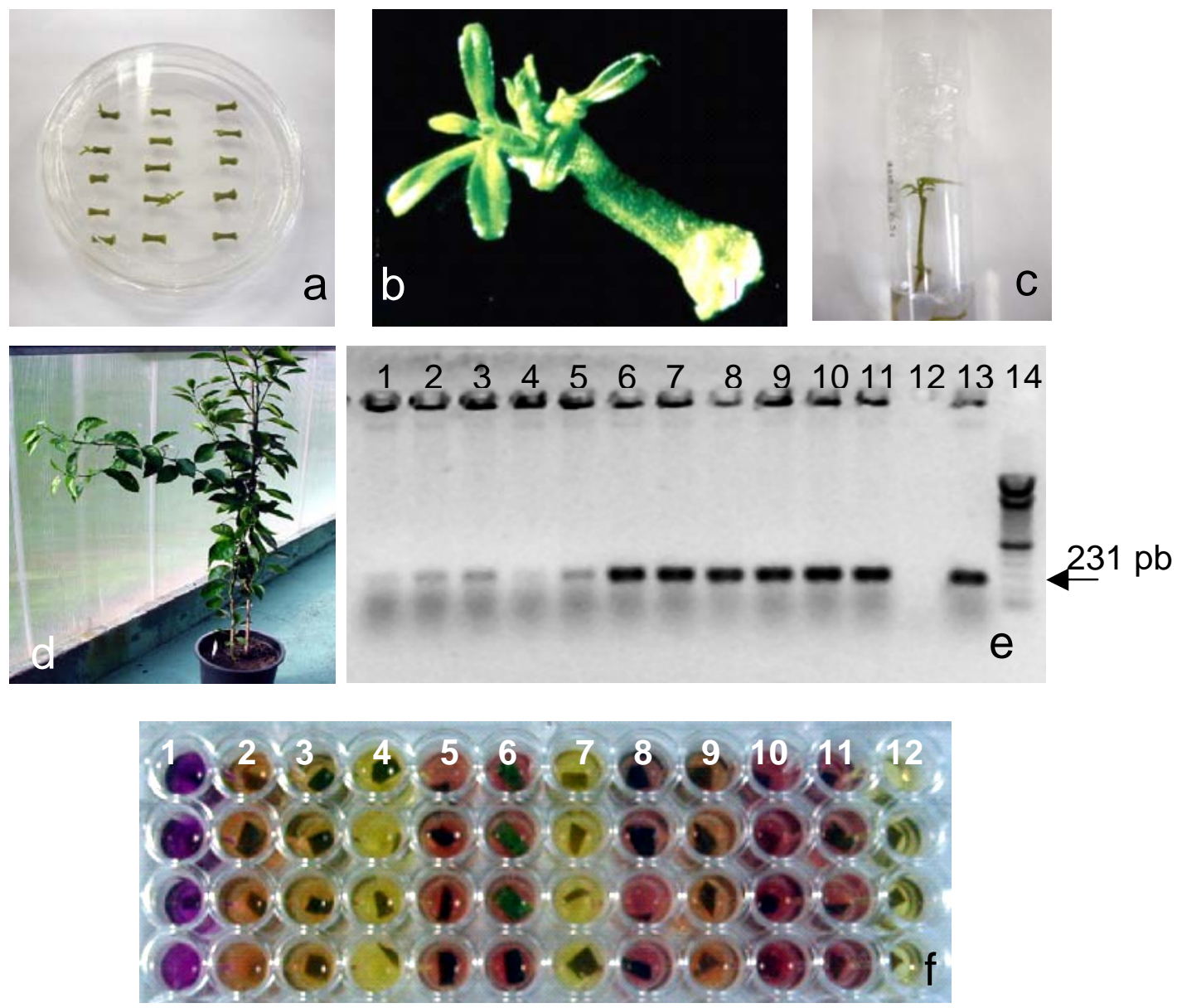

Figura 2 - Transformação genética a partir de segmentos de epicótilo de laranja doce (C. sinensis) 'Natal', 'Valência' 'Hamlin e 'Pêra'.

a) segmentos de epicótilo após 30 dias de cultivo; b) Brotações regeneradas cultivadas em meio seletivo contendo xilose como fonte de carboidrato; c) Plantas microenxertadas em citrange Carrizo; d) planta aclimatizada e cultivada em casa de vegetação; e) análise de PCR. Coluna $14=$ ladder 100 pb. Coluna $13=$ controle positivo consistindo do plasmídeo. Coluna 12 = controle negativo consistindo de uma planta não transformada. Colunas 1,2,3,4,5,6,7,8,9,10,11 = plantas positivas para o gene xylA. f) Análise com o indicador de $\mathrm{pH}$ clorofenol vermelho. Coluna 1 = plantas não transformadas. Coluna 2,3,4,5,6,7,8,9,10,11,12 são plantas $\mathrm{PCR}^{+}$para o gene xylA 


\section{CONCLUSÕES}

- Com base nos resultados obtidos neste trabalho pode-se concluir que é possível a regeneração de plantas transgênicas de variedades de laranja doce de citrus utilizando-se o sistema de seleção positiva xyIA/xilose. 


\section{REFERÊNCIAS BIBLIOGRÁFICAS}

ALMEIDA, W.A.B.; MOURÃO-FILHO, FA.A.; MENDES, B.M.J.; PAVAN, A.; RODRIGUES, A.P.M. Agrobacterium-mediated transformation of citrus sinensis and Citrus limonia epicotyl segments. Scientia Agricola, v.60, n.1, p. 23-29, 2003.

BAILEY, M.A.; KAEPPLER, H.F. Alternative markers for plant transformation. In Vitro Cellular and Development Biology. - Plant, v. 37, p. 101-102, 2001.

BOND, J.E.; ROOSE, M.L. Agrobacterium-mediated transformation of the commercially important citrus cultivar Washington navel orange. Plant Cell Reports, v.18, p.229-234, 1998.

BOSCARIOL R.L.; ALMEIDA W.A.B.; DERBYSHIRE M.T.V.C.; MOURÃOFILHO F.A.A.; MENDES B.M.J. The use of PMI/mannose selection system to recover transgenic sweet orange plants (Citrus sinensis L. Osbeck). Plant Cell Reports, v. 22, p.122-128, 2003.

BRASILEIRO, A.C.M.; DUSI, D.M.A. Transformação genética de plantas. In: TORRES, A.C.; CALDAS, L.S.; BUSO, J.A. (Ed.). Cultura de tecidos e transformação genética de plantas. Brasília: EMBRAPA, 1999. p.679735. 
CERVERA, M.; LOPEZ, M.M.; NAVARRO, L.; PEÑA, L. Virulence and supervirulence of Agrobacterium tumefaciens in woody fruits plants. Plant Pathology, v.52, p.67-68, 1998a.

CERVERA, M.; ORTEGA, C.; NAVARRO, A.; NAVARRO, L.; PEÑA, L. Generation of transgenic citrus plants with the tolerance-to-salinity gene HAL2 from yeast. Journal of Horticultural Science \& Biotechnology, v.75, p.26-30, 2000.

CERVERA, M.; JUÁREZ, J.; NAVARRO, A.; PINA, J.A.; DURÁN-VILA, N.; NAVARRO, L.; PEÑA, L. Genetic transformation and regeneration of mature tissues of woody fruit plants bypassing the juvenile stage. Transgenic Research, v.7, p.51-59, 1998b.

COSTA, M.G.C.; ALVES, V.S.; LANI, E.R.G.; MOSQUIM, P.R.; CARVALHO, C.R.; OTONI. W.C. Morphogenic gradients of adventious bus and shoot regeneration in epicotyl explant of citrus. Scientia Horticulturae, 2003 (No Prelo).

DESSAUX, Y.; PETIT, A.; TEMPÉ, J. Chemistry and biochemistry of opines chemical mediators of parasitism. Phytochemistry, v.34, p.31-38, 1993.

DOMÍNGUES, A.; GUERRI, J.; CAMBRA, M.; NAVARRO, L.; MORENO, P.; PEÑA, L. Efficient production of transgenic citrus plants expressing the coat protein gene of citrus tristeza virus. Plant Cell Reports, v.19, p.427-433, 2000.

FAO. Production yearbook, 2003. http://apps.fao.org (20 Oct de 2003). 
FEBRES, V.J.; NIBLETT, C.L.; LEE, R.F.; MOORE, G.A. Characterization of grapefruit plants (Citrus paradisi Macf.) transformed with citrus tristeza closterovirus genes. Plant Cell Reports, v.23, p.421-428, 2003.

FEICHTENBERGER, E. Manejo ecológico das principais doenças fúngicas e bacterianas dos citros no Brasil. In: SEMINÁRIO INTERNACIONAL DE CITROS: TRATOS CULTURAIS, 5., Bebedouro, 1998. Anais Bebedouro: Fundação Cargill, 1998. p. 23-63.

FLEMING, G.H.; OLIVARES-FUSTER, O.; FATTA DEL-BOSCO, S.; GROSSER, J.W. An alternative method for the genetic transformation of sweet orange. In Vitro Cellular and Development Biology-Plant, v.36, p.450-455, 2000.

FNP CONSULTORIA \& COMÉRCIO. AGRIANUAL 2003: anuário da agricultura brasileira. São Paulo, 2003. 536p.

FUNDECITRUS. Morte súbita dos citros: a informação é a sua melhor arma. Araraquara, 2003b. s.p.

FUNDECITRUS. http://www.fundecitrus.com.br (17 nov. 2003a). 
GHORBEL, R.; JUÁREZ, J.; NAVARRO, L.; PEÑA, L. Green fluorescent proteinas a screenable marker to increase the efficiency of generating transgenic woody fruit plants. Theoretical and Applied Genetics, v.99, p.350-358, 1999.

GMITTER JUNIOR, F.G.; HU, X.L. The possible role of Yunnan, China, in the origin of contemporary Citrus species (Rutaceae). Economic Botany, v.44, p. 267-277. 1990.

GMITTER JUNIOR, F.G.; GROSSER, J.W.; MOORE, G.A. Citrus. In: HAMMERSCHLAG, F.A.; LITZ, R.E. (Ed.). Biotechnology of perenial fruit crops. Cambridge: University Press, 1992, cap.14, p.335-369.

GMITTER JUNIOR, F.G.; LOUZADA, E.S.; DENG, Z.; HUANG, S. A bacterial artificial chromosome (BAC) library for cloning a citrus tristeza virusresistance gene. Acta Horticulturae, n.461, p.355-359, 1998.

GROSSER, J.W. The role of biotechnology in the development of improved Citrus scion and rootstock cultivars. Transactions of the 1992 Citrus Engineering Conference. American Society of Mechanical Engineers. Lakeland, Florida. v.38, p.24-37. 1992.

GROSSER, J.W.; GMITTER JUNIOR, F.G. Protoplast fusion and citrus improvement. Plant Breeding Reviews, v.8, p.339-374, 1990a.

GROSSER, J.W.; GMITTER JUNIOR, F.G.; CHANDLER, J.L. Somatic hybrid plants from sexually incompatible woody species: Citrus reticulata and Citropsis gilletiana. Plant Cell Reports, v.8, p.656-659, 1990. 
GUTIÉRREZ, E.; LUTH, D.; MOORE, G.A. Factors affecting Agrobacteriummediated transformation in Citrus and production of sour orange (Citrus aurantium) plants expressing the coat protein gene of citrus tristeza virus. Plant Cell Reports, v.16, p.745-753. 1997.

HALDRUP A.; NOERRENMARK, M.; OKKELS F.T. Plant selection principle based on xylose isomerase. In Vitro Cellular and Developmental BiologyPlant, v. 37, p. 114-119, 2001.

HALDRUP, A.; PETERSEN, S.G.; OKKELS, F.T. Positive selection: a plant selection principle based on xylose isomerase, na enzyme used in the food industry. Plant Cell Reports, v.18, p.76-81, 1998a.

HALDRUP, A,; PETERSEN, S.G,; OKKELS, F.T. The xylose isomerase gene from Thermoanaerobacterium thermosulfurogenes allows effective selection of transgenic plant cells using D-xylose as the selection agent. Plant Molecular Biology, v. 37, p.287-296, 1998b.

HIDAKA, T.; OMURA, M.; UGAKI, M.; TOMIYAMA, M.; KATO, A.; OHSHIMA, M.; MOTOYOSHI, F. Agrobacterium-mediated transformation and regeneration of Citrus spp. from suspension cells. Japanese Journal of Breeding, v.40, p.199-207, 1990.

JOERSBO, M,; OKKELS, F.T. A novel principle for selection of transgenic plant cells: positive selection. Plant Cell Reports, 16: 219-221, 1996.

LEITE JUNIOR, R.P.; BESPALHOK, J.C.; VIEIRA, L.G.E. Desenvolvimento de plantas transgênicas de citros para obtenção de resistência a doenças. In Anais $7^{\circ}$ Seminário internacional de citros melhoramento, p.74-81, 2002. 
KANEYOSHI, J.; KOBAYASHI, S.; NAKAMURA, Y.; SHIGEMOTO, N.; DOI, Y. A simple and efficient gene transfer system of trifoliate orange (Poncirus trifoliata Raf.). Plant Cell Reports, v.13, v.541-545, 1994.

KOBAYASHI S.; UCHIMIYA H. Expression and integration of a foreign gene in orange (Citrus sinensis Osb.) protoplasts by direct DNA transfer. Japanese Journal Genetics, v.64, p.91-97, 1989.

KOBAYASHI, A.K.; BESPALHOK FILHO, J.C.; PEREIRA, L.F.B.; MOLINARI, H.B.C.; GALVÃO, R.M.; VIEIRA, L.G.E. Agrobacterium-mediated transformation of sweet orange cv. Pera (Citrus sinensis L. Osbeck) with sarcotoxin antibacterial peptide gene. In: ENCONTRO LATINOAMERICANO DE BIOTECNOLOGIA VEGETAL, 4, Goiânia, 2001. Resumos. Goiânia, 2001. p.125.

MENDES B.M.J.; BOSCARIOL R.L.; MOURÃO FILHO F.A.A.; ALMEIDA W.A.B. Agrobacterium-mediated transformation of citrus Hamlin cultivar (Citrus sinensis L. Osbeck) epicotyl segments. Pesquisa Agropecuária Brasileira, v.37, n.7, p. 955-961, 2002.

MOLINARI, H.B.B.; BESPALHOK, J.C.; KOBAYASHI, A.K.; PEREIRA, L.F.P.; VIEIRA, L.G.E. Agrobacterium tumefasciens-mediated trasnsformation of Swingle citrumelo (Citrus paradisi Macf. X Poncirus trifoliata L. Raf.) using thin epicotyl sections. Scientia Horticulturae, 2003, (No Prelo).

MOORE, G.A.; JACOMO, C.C.; NEIDIGH, J.L.; LAWRENCE, S.D.; CLINE, K. Agrobacterium-mediated transformation of Citrus stem segments and regeneration of transgenic plants. Plant Cell Reports, v.11, p.238-242, 1992. 
MOREIRA-DIAS, J.M.; MOLINA, R.V.; GUARDIOLA, J.L.; GARCÍA-LUIS, A. Daylength and photon flux density influence the growth regulator effects on morphogenesis in epicotyl segments of Troyer citrange. Scientia Horticulturae, v.87, p.275-290, 2000.

MÜLLER, G.; DE NEGRI, D. Nova doença nos pomares: morte súbita dos citros. Citricultura Atual, v.5, n.25, p.12-13, 2001.

MÜLLER, G. Morte Súbita dos citros: uma nova doença na citricultura brasileira. Laranja, v.23, n.2, p. 371-386, 2002.

MURASHIGE T., SKOOG F. A revised medium for rapid growth and bioassay with tobacco tissue culture. Physiologia Plantarum, v.15, p.473-497, 1962.

NAVARRO, L.; OlIVARES-FUSTER, O.; JUAREZ, J.; ALEZA, P.; PINA, J.A.; CERVERA,M.; FAGOAGA, C.; PEREZ. R.M.; PEÑA, L. Melhoramento de citros na Espanha através da regeneração de triplóides, hibridação somática e transformação genética. In: $7^{\circ}$ SEMINÁRIO INTERNACIONAL DE CITROS MELHORAMENTO, p.57-70, 2002.

NEGROTTO, D.; JOLLEY, M.; BEER, S.; WENCK, A.R.; HANSEN, G. The use of phosphomannose-isomerase as a selectable marker to recover transgenic maize plants (Zea mays L.) via Agrobacterium transformation. Plant Cell Reports, v.19, p.798-803, 2000.

NEVES, E.M.; BOTEON, M. Impactos alocativos e distributivos na citricultura. Preços Agrícolas, n.136, p.3-6, 1998. 
NEVES, E.M.; NEVES, M.F. Suco concentrado de laranja. Uma commodity sui generis. Preços Agrícolas, v.10, n.114, p.11-13, 1996.

OGER, P.; PETIT, A.; DESSUX, Y. Genetically engineered plants producing opines alter their biological environment. Nature Biotechnology, v.15, p.369-372, 1997.

OLLITRAULT, P.; LURO, F. Amélioration des agrumes et biotechnologie. Fruits, v.50, p.267-279, 1995.

PEÑA, L.; CERVERA, M.; JUÁREZ, J.; NAVARRO, A.; PIÑA, J.A.; NAVARRO, L. Genetic transformation of lime (Citrus aurantifolia Swing.): factors affecting transformation and regeneration. Plant Cell Reports, v.16, p.731737, 1997.

PEÑA, L.; MARTIN-TRILLO, M.; JUÁREZ, J.; PINA, J.A.; NAVARRO, L.; MARTINEZ-ZAPATER, J.M. Constitutive expression of arabidopsis LEAFY e APETALA1 genes in citrus reduces their generation time. Nature Biotechnology, v. 19, p.263-267, 2001.

PEÑA, L.; CERVERA, M.; JUÁREZ, J.; NAVARRO, A.; PIÑA, J.A.; DURÁNVILA, N.; NAVARRO, L. Agrobacterium-mediated transformation sweet orange and regeneration of transgenic plants. Plant Cell Reports, v.14, p.616-619, 1995a.

PEÑA, L.; CERVERA, M.; JUÁREZ, J.; ORTEGA, E.; PIÑA, J.A.; DURÁN-VILA, N.; NAVARRO, L. High efficiency Agrobacterium-mediated transformation and regeneration of citrus. Plant Science, v.104, p.183-191, 1995b. 
PENNA, S.; SAGI, L.; SWENNEN, R. Positive selectable marker genes for routine plant transformation. In Vitro Cell Biology-Plant, v.38, p.125-128, 2002.

PÉREZ-MOLPHE-BALCH E., OCHOA-ALEJO, N. Regeneration of transgenic plants of Mexican lime from Agrobacterium rhizogenes-transformed tissues. Plant Cell Reports, v.17, p.591-596, 1997.

POMPEU JUNIOR., J. Porta-enxertos. In: RODRIGUES, O; VIÉGAS, F.; POMPEU JUNIOR, J.; AMARO, AA. (Ed.). Citricultura brasileira. Campinas: Fundação Cargill, 1991. v.1, p.281-296.

PRIVALLE L.S.; WRIGHT M.; REED J.; HANSEN G.; DAWSON J.; DUNDER E.M.; CHANG Y.; POWELL M.L.; MEGHJI M; Phosphomannose isomerase, a novel selectable plant selection system: mode of action and safety assessment In: Fairbain C, Scoles G \& Mcttughen A (Ed) Proc. $\mathbf{6}^{\text {th }}$ Int Symp biosafety Genet Modified Organisms. University Extension Press. University of Saskachewan, p.171-178, 1999.

RODRIGO, I.; VIEIRA, P.; TORNERO, P.; HERNANDES-YAGO, J.; CONEJERO, V. cDNA cloning of viroid-induced tomato pathogenesis-related protein p23. Caracterization as a vacuolar antifugal factor. Plant Physiology, v.102, p.939-945, 1993.

SALVA, R. Citrus tree production in Brazil. In: INTERNATIONAL CONGRESS OF CITRUS NURSERYMEN, 6., Ribeirão Preto, 2001. Proceedings. Ribeirão Preto: EECB,Fundecitrus, 2001. p. 11-16. 
SCORA, R.W. On the history and origin of Citrus. Bulletin of the Torrey Botanical Club, v.102, p.369-375. 1975.

SÃO PAULO (Estado) SECRETARIA DE AGRICULTURA E ABASTECIMENTO. Cadeia de produção de citros e a morte súbita: análise e estratégias da Secretaria de Agricultura e Abastecimento do governo de São Paulo, 12p, 2003.

SHENG, J.; CITVSKY, V. Agrobacterium-plant cell DNA transport: have virulence proteins, will travel. Plant Cell, v.8, p.1699-1710, 1996.

SOOST, R.K.; CAMERON, J.W. Citrus. In: JANICK, J.; MOORE, J.N. (Ed.) Advances in fruit breeding. West Lafayette: Purdue University Press, 1975. p.507-540.

SWINGLE, W.T.; REECE, P.C. The botany of citrus and its wild relatives. In: REUTHER, W.; WEBBER, H.J.; BATCHELOR (Ed.). The citrus industry. Berkeley: University of California Press, 1967. p.190-430.

TIMMER, L.W.; GARNSEY, S.M.; GRAHAM, J.M. Compedium of citrus diseases. St. Paul: APS Press, 2000. 80p.

TINLAND,B. The integration of T-DNA into plant genomes. Trends in Plant Science,v.1, p.178-183, 1996.

VARDI A.; BLEICHMAN S.; AVIV D. Genetic transformation of Citrus protoplasts and regeneration of transgenic plants. Plant Science, v.69, p.199-206, 1990. 
VIEGAS, F.C.P.; GUIMARÃES, J.A.B. Citrus fruit for processing in Brazil. In: INTERNATIONAL CONGRESS OF FRUIT JUICE, 11., São Paulo, 1991. Anais. São Paulo, 1991. p.1-27.

VIEIRA, M.L.C.; QUECINI, V.M. Biotecnologia na agricultura e na agroindústria. Agropecuária, p. 279-331, 2001.

WANG A.S., EVANS R.A., ALTENDORF P.R., HANTEN J.A., DOYLE M.C., ROSICHAN J.L. A mannose selection system for production of fertile transgenic maize plants from protoplasts. Plant Cell Reports, v.19, p.654$660,2000$.

WRITGTH, M.; DAWSON, J.; DUNDER, E.; SUTTIE, J.; REED, J.; KRAMER, C.; CHANG, Y.; NOVITZKY, R.; WANG, H.; ARTIM-MOORE, L. Efficient biolistic transformation of maize (Zea mays .L) and wheat (Triticum aestivumL.) using the phosphomannose isomerase gene, pmi, as the selectable marker. Plant Cell, v. 20, p.429-436, 2001.

YANG, Z.N.; INGELBRECHT, I.L.; LOUZADA, E.; SKARIA, M.; MIRKOV,T.E. Agrobacterium-mediated transformation of the commercially important grapefruit cultivar Rio Red (Citrus paradisi Macf.) Plant Cell Reports, v.19, p.1203-1211, 2000.

YAO, J.L.; WU, J.H.; GLEAVE, A.P.; MORRIS, B.M. Transformation of citrus embryogenic cell using particle bombardment and production of transgenic embryos. Plant Science, v.113, p.175-183, 1996. 
ZUBRZYCKI, H.M. Produção de frutas cítricas no nordeste argentino na presença do cancro cítrico (Xanthomonas axonopodis pv. citri). In: SEMINÁRIO INTERNACIONAL DE CITROS: TRATOS CULTURAIS, 5., , Bebedouro, 1998 Anais. Bebedouro: Fundação Cargill, 1998. p. 251-272.

ZUPAN, J.; ZAMBRYSKI, P. Transfer of DNA from Agrobacterium to the plant host cell. Plant Physiology, v.107, p. 1041-1047, 1995. 